\title{
Buddhism, Nationalism and War: A Comparative Evaluation of Chinese and Japanese Buddhists' Reactions to the Second Sino-Japanese War (1937 1945)
}

\author{
Dong Zhao
}

\begin{abstract}
This paper tries to give a theoretical and historical framework of the intimate link between Chinese and Japanese Buddhism, nationalism and militarism evidenced by the Second Sino-Japanese War. It analyzes how the Buddhist monks in both China and Japan, despite Buddhism's traditionally ahimsa philosophy, participated in the fierce violence of the Second Sino-Japanese War from a historical perspective. In sum, Buddhism has played an essential role in reevaluating the Second Sino-Japanese War, and more insights can therefore be gained on the complicated relationship between religion, polity and violence.
\end{abstract}

Index Terms-Buddhism, nationalism, violence, Sino-Japanese War.

\section{INTRODUCTION}

The Second Sino-Japanese War (1937 to 1945) was a major war fought between China and Japan, the largest Asian war in the twentieth century. In Chinese, the war is known as the War to Resist the Japanese Invasion or The Anti-Japanese War (抗日战争), while in Japan it is known as "HEI" or the "C" Operation (or simply as 日中战争, nicchuusensou, Japanese-Chinese War). Most Chinese scholarship on it has been done from historical perspectives, exploring the history of this war period including historical documentation, the Japanese atrocities (particularly the Nanjing Massacre), the Chinese Communist Party-led Anti-Japanese movements (especially about the United Fronts), and the resistence efforts made by the Nationalist Party. Ever since the 1970s, Western monographs on it have focused on topics ranging from Japan's rule of the Northeast China through Sino-Japanese military histories to foreign policies of both countries during this period. Most recent researches are in the angles of literature, culture and education as influenced by this war, i.e. how the war is reflected differently in the literatures of the two countries, how war propaganda transformed literary forms and education purposes. The Chinese academic perspective is restrained by the lens of patriotism and nationalism with even a Beijing based quarterly journal serving this function, The Journal of Studies of China's Resistance War Against Japan (kangri zhanzheng yanjiu) while the Western is overwhelmingly against this academic taste in order to be historically objective through sociological and anthropological perspectives.

Trying to break a piece of new ground, this paper tries to give a theoretical and historical framework of the intimate link between Chinese and Japanese Buddhism, nationalism and militarism evidenced by the Second Sino-Japanese War. In Chinese views, the war was launched by Japanese imperialists after longtime plotting to invade China. On the Chinese part, a considerable number of Chinese Buddhist monks, influenced by the Buddhist reform movement, began to realize that under the context of nationalism, Buddhism would contribute to the nation. During the war, Chinese patriotic Buddhists probed into the cause of the Japanese invasion and disclosed the theory behind its invasion from Buddhist perspectives. They cited Buddhist Scriptures as evidence to show that killing enemies for protecting the country did not go against Buddhist teachings. Meanwhile, many monks struggled in reconciling their Buddhist commitment to non-violence (ahimsa) with their obligation as citizens to defend the nation in time of national crisis. This paper reevaluates the doctrinal grounds and actual practices of this "new Buddhist tradition," a striking and startling contrast to the Buddhist teachings of non-violence and compassion, by resorting to some previously little examined textual sources and historical documents.

Japanese Buddhism has always been deeply involved in politics and defending the nation against external threats is its primary task. The notion that Buddhism has a unique contribution to the protection and perpetuation of the Japanese state has been a fixture of Buddhist thought since at least the Heian period. Zen priests and scholars were among the most zealous supporters and avid apologists for Japan's wars. Zen Buddhism became the most aggressive and visible defender of imperial Japan and its sacred National Polity. Throughout the Second Sino-Japanese War, various Japanese Buddhist sects supported Japanese governments in invading China, setting up their sects and temples and preaching in numerous areas of the war-stricken China. Prominent Buddhist thinkers like Inoue Enryd and D. T. Suzuki had advocated sacrificing one's physical existence for the sake of the emperor. In sum, Buddhism has played an essential role in reevaluating the Second Sino-Japanese War, and more insights can therefore be gained on the complicated relationship between religion, polity and violence.

\section{Chinese Buddhist Monks' Justification OF the ANTI-JAPANESE WAR}

The Chinese nationalistic sentiments and movements in 
the early $20^{\text {th }}$ century were a result of both internal conflicts and foreign invasions. The Chinese government and people, lay and clergy alike, wanted to build a unified China and defend her from international aggressions. In the aspect of Buddhism, which entered China as early as the second century B C, Buddhist leaders and reformers had to think about the survival and development of Buddhism when this religion expected to take root in an atheist nation in time of crisis. And this crisis, national in nature, also signified that Buddhists had to undertake self-reform and social engagement, especially when external religions, such as Christianity and Japanese Buddhism, were competing for influence. Under such a historical context, Buddhism felt a wave of reform when the republic was established. The Buddhist monasteries set up schools for sangha and children; a magazine was even published which issued several numbers irregularly; a national organization was established with Peking as its headquarters; and the activities in lecturing and propaganda were increased. First led by lay Buddhist reformers like Yang Renshan and later by social elites and even politicians, the movement aimed to revitalize Buddhism by printing texts to educate people with the Buddhist philosophical views of life and to implement social and political reforms in China.

Under this prevailing nationalistic atmosphere in China, Chinese Buddhists, especially the youth, began to reconsider the Buddhist non-violence conceptions and actively engage themselves in defending the nation. The civic duties of the Buddhists demanded that they temporarily abandon their religious adherence in a time when every citizen had the obligation to take up arms to guard national sovereignty. On June 1, 1931, the Provisional Constitution of the Political Tutelage Period was announced. Its Second Article stipulated that "All persons who, according to the law, enjoy the nationality of the Republic of China and shall be citizens of the Republic of China," and its Sixth Article stated that "All citizens of China are equal before the Law, irrespective of sex, race, religion or caste." Moreover, Article 1 of Military Service Law of the People's Republic of China: This Law is enacted pursuant to Article 55 of the Constitution of the People's Republic of China which stipulates, " it is the sacred duty of every citizen of the People's Republic of China to defend the motherland and resist aggression. It is the honorable duty of citizens of the People's Republic of China to perform military service and join the militia in accordance with the law," and in accordance with other relevant provisions of the Constitution. Article 3: All citizens of the People's Republic of China, regardless of ethnic status, race, occupation, family background, religious belief and education, have the obligation to perform military service according to the provisions of this Law. These articles combined to show that Buddhist monks, like any other Chinese citizens, had the obligation to offer service to the country, and such services necessarily included military service in time of war. The young monks, having revolution and reform in their mind, eagerly participated in military training for the future of the nation as well as Buddhism. Their answer to the call of the government demonstrates their patriotism and their confirmation that Buddhism could indeed benefit the nation, thus having strong reasons for its

\section{existence.}

On the other hand, though the national crisis necessitated military actions on the part of the monks, those monks involved had to prove to others that what they were doing did not violate the general Buddhist doctrines of non-killing and non-violence. In Buddhist monk Zhen Hua (震华法师)'s book The History of Sanhga Protecting the Nation was recorded how the monks helped the nation by doing military training and collecting money for the troops during the period of the Anti-Japanese War [1]. In this book, Zhen Hua further elucidated the meaning of Huguo/ 护国 (protecting the nation). He referred to the Buddha as a Protector of Nation in that he reformed the traditions of India and tried to guide the whole world onto the right path. To him, Buddhist nation protecting can be explained in both a narrow and a wide sense: in the narrow sense, nation protecting means the clergy tending their own business and benefiting themselves, or "passive nation protecting"; whereas in a wider sense, it denotes that a monk should try to benefit others by doing things outside of their own business, or "active nation protecting".

Under such circumstances of foreign invasion and national crisis, the revolutionary (the Chinese sense of the word meaning "noble or upright") monks had to reread Buddhist cannons to redefine (or even abandon in some extreme cases) their religious convictions so as to justify their participation in war. They quote a central tenet of Mahayana Buddhism: Compassion is fundamental: be skillful in practice; Compassion is the Buddhist virtue. Being skillful shows your wisdom in handling worldly affairs. Therefore, as is interpreted by the monks, compassion and skillfulness might supersede the doctrine of non-killing when killing a few could actually save many other innocent lives. Chapter 41 of Yogācārabhūmi is often cited by Chinese monks to explicate the doctrine of "killing one to save many." In this chapter can be found a story in which a bodhisattva killed a small number of bandits who intended to kill many people to rob their riches. This act is valued as benevolent, not evil.

In order to prove their patriotism and support of the state, Chinese monks named quite a few of their temple "Huguosi" (Temples Protecting the Nation) and some prominent Buddhist masters "guoshi" or "fashi" (Master of the State or Master of Law). They know that their existence depends on the state for food and clothing since they themselves did not participate in agriculture and that none of them is willing to be a "wangguonu" (a slave in a destroyed country). So monks should take up weapons to engage in military training and to be soldier monks in the war against Japanese aggression. On this point the Nirvana Sutra again came to their help: "Again the Buddha said: 'Even though there may be those who observe the five precepts, they do not deserve to be called practitioners of the great vehicle. But even if one does not observe the five precepts, if one defends the correct teaching, then one may be called a practitioner of the great vehicle. Defenders of the correct teaching ought to arm themselves with knives and swords, weapons and staves. Even though they carry swords and staves, I would call them men who observe the precepts." With the slogan of "putting down the Buddhist service instruments and taking up arms," young monks were encouraged to learn Shaolin martial arts in order 
to protect the nation, as Shaolin monks had done earlier in Chinese history. Therefore, "protecting the independence and freedom of a country and resisting foreign aggression and oppression belong to the correct teaching" [2]. This is the true meaning of "Huguo" (Protecting Nation), in the spirit of Renwang Jing (The Benevolent King Sutra).

Meanwhile, leading Chinese monks like Taixu 太虚 were bent on analyzing the reason of Japan's invasion of China and exposing the Japanese Buddhist schemes behind it To Tai $\mathrm{Xu}$, the spirit of extreme self-importance is root of Japanese military imperialism, leading the Japanese to despise and enslave others. In order to eliminate the imperialistic sentiments and thus to achieve world peace, people had to dig into the root of man's kindness or brutality, which, according to the Buddhist principle, was "The Heart" (xin 心). Only when the heart of the Japanese invaders was purified, would they stop all aggressive practices. Therefore, a number of Buddhist journals like Shizihou (Roaring Lion) appeared to condemn the Japanese invasion and heighten the Chinese nationalistic spirit. Chinese Buddhists pointed out that the Japanese aggression was driven by Devil from the Five Aggregates (Wuyunmo 五蕴魔) and the Japanese invaders were now turning into devils that disturb people's peaceful life and destroy people's happiness. In this war the sangha were the valiant warriors ready to conquer the devils and step on the path of eventually becoming a Buddha.

\section{Chinese Buddhist MONKS' PARTICIPATION IN THE ANTI-JAPANESE WAR}

Chinese Buddhist participation in the war took various forms, the more direct and influential ones being Buddhist rescue and first-aid teams, Buddhist ritual ceremonies for the nation, and Buddhist military training and guerrilla activities. According to the story of Buddha's taking care of a sick old monk, Chinese Buddhist monks, including those who could not accept the theory and practice of "compassionate killing," started to set up rescue teams and first-aid groups to help wounded soldiers and civilians in the war. The best known rescue teams included "Shanghai Buddhist Rescue Team," "Shanghai Unified Aid Committee," and "Chongqing Ciyun Temple Rescue Team." Shortly after the July 7 Incident of 1937, "Shanghai Buddhist Rescue Team" immediately went to the battle front and provided medical care and food to more than 8000 wounded Chinese soldiers and civilians. They were celebrated as "Heroic Monks" by Shanghai Newspaper. Master Shi Hongming of the "Shanghai Buddhist Rescue Team," seeing the shortages of medical personnel and supplies, called the whole society to help set up a "Buddhist Hospital." This call was immediately answered and within only a few days a temporary Buddhist hospital began to function. "Chongqing Ciyun Temple Rescue Team" of Sichuan Province, set up in March 1940, was the most noteworthy in that all members of them, unlike other rescue teams, had their own military uniforms, the most eye-catching feature being the Chinese character “佛” (Buddha) in red on the badge of their helmets. They braved the Japanese bombings and ferried over Jia Ling River to save injured Chinese soldiers. This event was reported in
"Xinmin Newspaper" and "Commercial Daily" of Sichuan Province.

The Chinese Buddhist monks also made donations to the nation through countless ritual performances. They carried out rituals for ending human disasters, blessing the nation, achieving victory in the war and restoring peace to the world. For instance, on July 7, 1939, a ritual ceremony was held in Kunming City, Yunnan Province to commemorate the second anniversary of the beginning of the war. In this ceremony, The Dharani of Great Compassion was recited time and again to invoke the blessing of Avalokitesvara Bodhisattva. A most telling instance of such patriotic rituals could be found in 1939, when the Chinese Anti-aggression warfare entered a stalemate and the Chinese troops were losing their morale. On Sep. 29, Dai Jitao, representing the Chinese Nationalist government, organized a grand ritual of about 2000 people, including Tibetan and Mongolian monks and officials, to pray in order to boost the spirit of the soldiers by transferring to them the merit of the soldiers who died in the war. And it must be pointed out that this grand esoteric ceremony was held only shortly after Dai Jitao renovated the Nation-Ptrotecting Buddhist Association.

Besides serving in rescue teams, collecting donations for the troops and performing rituals, the Chinese sangha also participated in military training and went directly to the battle field. The monks took off their monastic robes, put on military informs and carried out guerrilla activities against the Japanese troops. Even the temple became strategic points and battle fields. Some monks even disguised themselves as secret agents who hid themselves among people in Japanese occupied areas. Some of them got caught and killed, without leaving a name. The monks tried every "skillful means" to engage in all anti-Japanese activities as was requested by the war. In September 1937, the first group of about 300 hundred young monks, having received military training, went to the battle front to sacrifice their lives for the country. The slogan of Buddhist Society of Guilin established in April 1934 proclaimed that "In this critical moment of our nation, guided by Ksitigarbha's famous 'Who will redeem you if I do not go to hell,' we should go to the very battle front to defend our nation to realize the virtue of the Buddha" [3].

\section{JAPANESE BUDDHISM AND THE GLORIFICATION OF WAR}

The impact of Buddhism on Japan's political and religious development is impossible to exaggerate. Since its introduction to Japan, countless Buddhist masters like Kukai, Nichiren had been instrumental in employing Buddhism to serve and protect the nation. Japanese Buddhism has always been deeply involved in Japanese national spirit and politics and safeguarding the nation's survival is its primary task. In Japan, modern Buddhist nationalist movement was compelled by state Shinto and then voluntarily served Japan's imperialistic policy. Therefore, like its Chinese counterpart, Japanese Buddhism had to demonstrate its usefulness and inseparability to the nation [4]. The following slogans could exemplify the close alliance between Buddhism and the Japanese state: "revere the emperor and serve the Buddha" (sonno hobutsu), "love the country and protect the Dharma" (aikoku goho), "protect the country by 
promoting Zen," (kozen gokoku), and "pacify and preserve the country (through Buddhism)" (chingo kokka) [5]. According to D. T. Suzuki, one of the world's leading authorities on Zen Buddhism, author of more than a hundred works on the subject, Zen Buddhism

Typifies Japanese spirituality. This does not mean Zen has deep roots within the life of the Japanese people, rather that Japanese life itself is "Zen-like." The importation of Zen provided the opportunity for Japanese spirituality to ignite, yet the constituents themselves which were to ignite were fully primed at that time. [6]

As is evidenced in history, the Japanese religious policy has evolved from assertion of an exclusive national creed through passive tolerance of existing religions to incorporation of established religions to the ruling structure [7]. To Suzuki, Zen is the essence of not only Japanese Buddhism, but also the spirit of the Japanese nation.

"If ordered to march: tramp, tramp or shoot: bang, bang. This is the manifestation of the highest wisdom of enlightenment. The unity of Zen and war extends to the farthest reaches of the holy war now under way." This startling statement, made by Japanese Zen Master Harada Daiun Sogaku in 1939, led us to probe the root of the ties between Japanese Zen Buddhism, the state and military imperialism. Zen, as a school of Mahāyāna Buddhism, was first documented to have entered China in the 7th century and later spread to Japan in 1191. In the Meiji Restoration period in Japan, faced with the challenge of state Shinto, Buddhist institutions, like its Chinese counterpart, responded with "New Buddhism Movement", designed to show that Buddhism too could make valuable contributions to social and economic development, could promote loyalty to the throne, and was compatible with Western technology. And it did achieve this aim. With the emergence of Japan as a military and colonial power in Asia, its nationalistic spirit marked the spiritual and moral superiority of Japan, arguing that the Buddhism of Japan represents the most advanced form of the Buddha's teaching, insisting that pure Buddhism survives only in Japan. Nitobe Inazō, in his book Bushidō: The Soul of Japan (1969), described Zen Buddhism as the code of moral principles which the samurai were required or instructed to observe and more frequently it is a code an organic growth of decades and centuries of military career. Sometimes the Samurai qualities were regarded as the birthright of all Japanese and bushido was even codified as the expression of "Japaneseness" itself.

The combination of Buddhist and nationalistic ideologies was a characteristic feature throughout the history of Japan. Scholars of Buddhism and Buddhist masters often associate equate Buddhism with the state, the emperor, so terms like Imperial Way Buddhism, Imperial State Zen, etc. are often heard in Japan. Emperor Shōmu 聖武 (701 -756), regarding Buddhism's political potential as the foundation for political centralization, constructed Tōdaiji in Nara and subsidiary temples in each province. In this way, intimate ties between Buddhism and the government developed: the ordination of Buddhist monks and nuns was authorized and conducted by the government, and construction of temples was supported by the government with special tax considerations. Thus, the final result is that "the emergent discourse of a reconstructed
Zen is predicated upon, and inexorably enmeshed in, the nativist and imperialist ideology of late nineteenth- and early twentieth-century Japan" [8].

In 1896 when the Fist Sino-Japanese War began, D. T. Suzuki wrote, "religion should, first of all, seek to preserve the existence of the state." Echoing his teacher, he regarded the enemies of Japan as "unruly heathens" who must be conquered or who would otherwise "interrupt the progress of humanity. In the name of religion, our country could not submit to this." Going to the battlefield, to him, is a religious pilgrimage. Suzuki used poetic language to celebrate and boost the spirit of Japanese soldiers in battle. "Our soldiers regard their own lives as being as light as goose feathers while their devotion to duty is as heavy as Mount Taishan (in China). Should they fall on the battlefields, they have no regrets." This metaphor of "goose feathers" borrowed from China was a most influential military indoctrination, telling soldiers that their individual lives, compared with the noble cause of imperial war, were without any significance and had no weight. In this spirit, Zen Master Seki Seitetsu wrote a book promoting Zen and bushido. During the Second Sino-Japanese War, Seisetsu called forth to the soldiers over radio: "Showing the utmost loyalty to the emperor is identical with engaging in the religious practice of Mahayana Buddhism. This is because Mahayana Buddhism is identical with the law of the sovereign." He then called for the "extermination of the red devils" (Communists) both in Japan and in China. Seisetsu reinforced his message to the battlefield by visiting the Chinese front in 1938 .

\section{JAPANESE BUDDHIST MONKS' PARTICIPATION SECOND SINO-JAPANESE WAR}

In 1937, when Marco Polo Bridge Incident marked the overall warfare between China and Japan, D. T. Suzuki almost finished his worldly-known Zen and Japanese Culture, in which he asserted that Zen "treats life and death indifferently" and "is a religion that teaches us not to look backward once the course is decided." The Zen bushido creed of treating life and death indifferently was acted out in December 1937, when the Japanese soldiers seized Nanking, then the capital of the Republic of China and caused millions to die. Buddhist chaplains accompanied Japanese troops to the Chinese mainland battlefield as early as 1894, the starting year of the First Sino-Japanese war. They delivered talks to the soldiers to consolidate their fighting morale andconfidence in victory; they prayed in funerals for those killed in battle; and they were also in charge of giving notices to the relatives of the deceased in Japan. As is pointed out by Brian Victoria, even in times of peace Buddhist chaplains were also needed, with the Nishi (West) Honganji branch of the True Pure Land sect, for example, sending forty-six priests to more than forty military bases throughout Japan as early as 1902. Victoria points out that during the Sino-Japanese war "there was almost no peace movement among Buddhists, there was no lack of Buddhist leaders who justified the war" [9]. Phillip Kapleau's The Three Pillars of Zen best instructs on the concept of "War Zen," under which the whole universe is at "war." He argues that the truth of Dharma could be revealed only through the actual 
participation in war. It is impermissible to forget war even for an instant," he wrote. This view is shared and heightened by Brian Victoria when he quoted Harada's statement "The sword that kills is also the sword that gives life."

The first mission of Japanese Buddhists to China was conducted by Higashi Honganji temple in 1876, and the number of missionaries increased after the defeat of China in 1895. In the early 1930s, mission stations in China were close to a hundred, serving to implement the Japanese expansionist policy of "Great East Asia Co-prosperity Sphere" (Kyūjitai 大東亞共榮圈). The key concepts of "Imperial Way Buddhism" and "Nation Protecting Buddhism" guided all the Japanese Buddhist activities in wartime China. In the 30 s and $40 \mathrm{~s}$, the wartime missionary activities reached an unprecedented scale. At this time, Buddhist monks tried their utmost to serve the Japanese aggression of China, advocating that "The Buddha's law should cooperate with the imperial law." On July 22, 1937, Higashi Honganji Temple set up an office to manage affairs like comforting the troops and preaching. They handed out brochures, transported necessities to the battle field, held rituals for soldiers about to go to war, etc. It has to be pointed out that in order to justify military aggression, wartime Buddhism resorted even to distorting the Buddhist doctrines that were considered "inappropriate." From 1937 to 1944 there were altogether 135 changes to the Buddhist cannon made by the Lotus Sect, which even tried to tamper with the textbooks of Ryukoku University, declaring that Japan was the fountainhead of Buddhism [10].

In addition, almost all sects of Japanese Buddhism sent missionaries to "comfort" the soldiers in giving them spiritual consoles and praying for the dead soldiers. What's more remarkable is the fact that some Buddhist masters directly involved themselves in politics and guided the aggression of China. Count Otani Kozui (大谷光瑞, Buddhist name: 鏡如 Kyōnyo), the 22nd Abbot of the West Honganji Monastery of the Jodo Shinshu Buddhist sect in Kyoto, even became a member of the Cabinet and the Pan Asian Committee in 1940 . He promoted the policies of national expansion in China so as to reinvigorate Japan. In March 1940, Asian Buddhism Training Center was established to give monks strict military training and spirit of military aggression [11]. One more significant instance of Buddhist participation in the war is that in order to better serve the war, Japanese Buddhist associations in China began to hold cultural, educational and social training programs so as to pacify the Chinese people in the Japanese occupied areas. The purpose was to train personnel qualified for proselytizing and to reinforce military aggression and missionary activities. The trainees, from 1938 onward, began to include qualified Chinese high school graduates between 25-35 years old. The content of the training programs focused on knowledge of China, such as Chinese dialects, agriculture, population, medicine, poetry, geography, etc. Various Japanese Buddhist sects even went on to open schools, kindergartens, Young Men's associations, hospitals, clubs, relief centers, etc. to propagate the theories like "friendship between China and Japan." In a word, all such activities aimed to justify the Japanese aggression on a spiritual level, further pursuing the policy of appeasement.

According to the various sources of historical records, the basic responsibilities of a Buddhist chaplain accompanying the Japanese troops included the following: performing funereal rites (praying, cremation and burial) for the Japanese soldiers killed in battle; instructing the soldiers on Buddhism; comforting and treating the wounded; participating in combat; handing out prayer beads, scriptures, etc.; donating food and other goods for relief; pacifying the Chinese; reporting to home sects information regarding war as well as his own activities; establishing missionary agencies; and translating materials. Besides preaching to the soldiers that life and death are both empty and that the sword is the Buddha, the monks themselves did participate in the battle. It is recorded that in the Japanese attack of Nanking, the monks were so active and brave that they got quite a few "number ones" such as the first military chaplain to charge into Nanking city. Otani Kosho, Abbot of the West Honganji Monastery, was also with them at the time to boost the soldiers' morale; and in the press conference on December 25 after his return to Japan, he tried to wipe out the atrocities done by the Japanese soldiers to the Chinese by glamorizing what he had seen on the spot.

\section{CONCLUSION}

Buddhism is frequently eulogized as a religion marked by universal compassion. However, it does not unequivocally reject violence, retaining the possibility that violence may be employed under special circumstances, such as in a justifiable war or a national crisis. It does have strong apologetic defenses for the presence of violence and killing and advocate the concept of "compassionate killing", "compassionate violence" or the Tantric fierce compassion on exceptional occasions especially when such actions are performed by spiritually advanced beings. Meanwhile, Buddhism can also be viewed as a religio-political entity in itself, and the Buddha was, indeed, a profound social thinker who unfolded new ways of thinking about the place of the individual in society. And despite its preaching of peace and pacificism, it engages in ethnocentrism, nationalism and militarisms in the direction of a Buddhist nationalist ideology, though not yet institutionalized, as is showcased in this essay.

Religion has always generated the both the most sublime / altruist and most horrific / inhuman events in the human history. This point is best verified in the relationship between religion, the state and war / violence, where both noble acts and heinous crimes emerge under the name of religion. This paper has sought to answer the question of how the Buddhist monks in both China and Japan-despite Buddhism's traditionally nonviolent philosophy - are able to participate in the fierce violence of the Second Sino-Japanese War. From a historical perspective and under the lens of Buddhism, it contextualizes Buddhists' practices in the socio-political and religious environment of Wartime China and Japan to explore the nationalistic and patriotic motivations behind Buddhist support and participation in war. It concludes that modern nationalism and state building have brought Chinese and Japanese clergy alike to reinterpret, transcend or even distort Buddhist teachings to be involved in war. 


\section{REFERENCES}

[1] H. Zhen, The History of Sanhga Protecting the Nation, Shanghai: Shanghai Buddhist Studies Press, 1983, pp. 1-283.

[2] X. Tai, "Buddhism Protecting the Nation and the World," Haichaoyin, vol. 20, no. 1, pp. 167-182, Sep. 1939.

[3] Z. Ju, "Editorial," Shizihouyuekan (Monthly Journal of Roaring Lion), vol. 1, pp. 3, Dec. 1940.

[4] Y. Xue, Buddhism, War, and Nationalism: Chinese Monks in the Struggle against Japanese Aggressions, 1931-1945, New York: Routledge, 2005, pp. 393-398.

[5] W. Davis, "Buddhism and the Modernization of Japan," History of Religions, vol. 28, no. 4, 1989, pp. 308.

[6] D. T. Suzuki, Nihonteki Reisei, English translation by Norman Waddel, Japanese Spirituality, Tokyo: Japan Society for the Promotion of Science and Japanese Ministry of Education, 1972, pp. 18.

[7] S. M. Garon, "State and religion in imperial Japan, 1912-1945," Journal of Japanese Studies, vol. 12, no. 2, 1986, pp. 277.

[8] R. H. Sharf, "The Zen of Japanese nationalism," History of Religions, vol. 33, no. 1, 1993, pp. 11.

[9] B. V. Daizen, Zen War Stories, London: Rutledge Curzon, 2003, pp. 150-162, 20.

[10] Z. W. Yang, A History of Contemporary History of Buddhism in Japan, Zhejiang: Zhejiang People's Press, 1996, pp. 172-173.
[11] G. X. You, Shanghai Jindai Fojiao Jianshi (A Brief History of Contemporary Buddhism in Shanghai), Shanghai: East China Normal University Press, 1988, pp. 140.

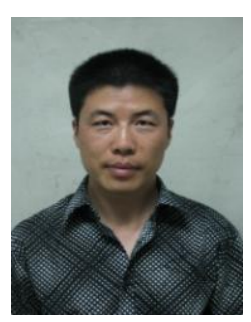

Zhao Dong was born in Liaoning Province, China in 1972. He got his Bachelor degree in English Language and Culture, and his Master degree in Religion and Literature from Dalian University of Foreign Languages, China. He received his doctoral degree in Religion and Literature from Beijing Foreign Studies University. He has research interests in Religious Studies from Cross-Cultural perspectives, Religion and Society, Religion and Literature, and Chinese Religions.

He received a national scholarship to be a one-year visiting scholar in Yale English Department and Divinity School from 2003 to 2004, and a Canadian government grant to do comparative studies of Chinese and Canadian minority religious policies in Canada from June to July in 2012. He has been teaching in Foreign Studies University since March, 2000 and became Associate Professor in 2008. The books he authored include The Scriptures and The Faerie Queen (2008), Selected Readings in British and American Poetry (with Chinese Translation)(2008), and Guided Readings in Classic Chinese Buddhist Sutras (in progress). He also published numerous articles both in Chinese and English in domestic and international academic journals. 